\title{
PROLIFIC FLOWERING YEAR FOR PLAINS ROUGH FESCUE AT THE KERNEN PRAIRIE
}

KENNETH TOYNBEE, Department of Crop Science and Plant Ecology, University of Saskatchewan, Saskatoon, Saskatchewan. S7N 0W0

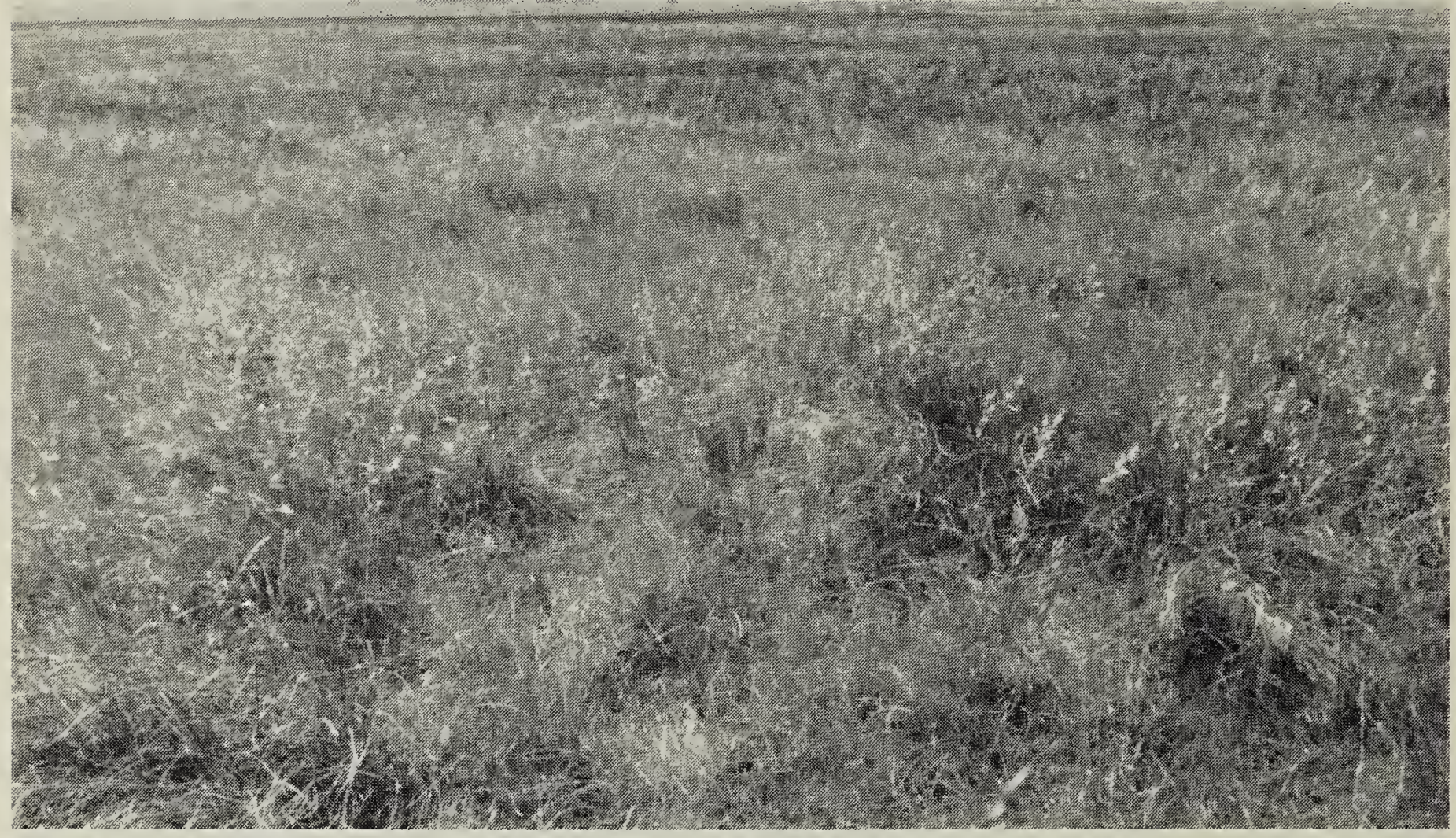

Figure 1. Plains Rough Fescue in flower at Kernen Prairie

Kenneth Toynbee

Plains Rough Fescue (Festuca altaica Trin. ssp. hallii (Vasey) Harms) is the dominant grass of the fescue grassland of Saskatchewan.' Flowering and seed set are relatively uncommon in this perennial grass. Johnston and MacDonald reported that ungrazed fescue in southern Alberta produced a good seed crop in 1902, 1952,1964 and 1966 and a poor crop in 1965 and 1967.2 Moss noted that John Macoun, an early botanist, had failed to record Plains Rough Fescue in the aspen parkland in the 1880s. ${ }^{3}$ He considered Western Porcupine Grass (Stipa spartea var. curtiseta) to be the dominant species of the area. Perhaps the typically small number of seed heads present, if any rnay explain Macoun's omission of Plains Rough Fescue, as well as the failure to recognize the fescue association in early grassland community classifications. ${ }^{15}$

At the Kernen Prairie natural area, a 130 ha grassland dominated by Plains Rough Fescue near Saskatoon, vigorous flowering was observed in 1987 (Fig. 1). Flowering was initiated around 10 May 1987 for a large number of fescue plants over the entire grassland, especially in unburned portions (Table 1). Flowering lasted from about 25 May until 7 June. Numbers of seed heads were counted on 30 quadrats 
Table 1. DENSITY OF SEED HEADS FOR PLAINS ROUGH FESCUE AT KERNEN PRAIRIE, SASKATCHEWAN.*

Treatment

Unburned

Fall 1986 burn

Early (27 April) spring burn

Late (6 May) spring burn
Seed heads $/ m^{2}$

Mean

Standard Deviation

224

112

24
4.66

5.21

8.90

0.54

* Counts of seed heads were made in early June 1987 on 30 quadrats $25 \mathrm{~cm}$ square 11

$25 \mathrm{~cm}$ square, on different treatments of unburned and fall or spring burned.

Plant ecologists and botanists familiar with the area reported that they had not observed this plant flowering so prolificalIy in the past. ${ }^{6}$ Documentation of this flowering will help determine future flowering intervals, and will help to determine what controls flowering in this grass species: Production of new individuals through seed production allows hybridization to occur which can increase the gene pool of the species, a factor which may enhance that species' survival.

Johnston and MacDonald found that the vegetative apices of rough fescue appeared to initiate floral primordia in late August to early September. ${ }^{2}$ The mild Saskatoon winter and spring of 1986-87 may have been a factor in the increased survival of the floral primordia and subsequent floral development. They also found that heading occurred in late June when the soil temperature at a $20 \mathrm{~cm}$ depth reached $12.7^{\circ} \mathrm{C} .{ }^{2}$ The warmer than normal spring weather may have brought the soil temperature to 12.7 earlier than normal. Another factor might have been the low frequency of killing frosts during the spring.

Table 1 illustrates that burning reduced the density of inflorescences. Both spring and fall burning disrupted the flowering; the spring burns caused the most detrimental effect. In this case it appears that the high temperatures during the fires may have killed many floral primordia, thereby reducing flowering.

Although there is abundant floral development, not all the flowers may produce viable seed. Preliminary sampling on 22 June showed most spikelets at the milk stage of seed development, indicating that the plants are producing seed. Further observations will be carried out to determine seed productivity and viability.

\section{Acknowledgements}

The constructive comments from A. Schwarz, B. Pylypec, R.E. Redman, V.L. Harms and J. Romo in reviewing the manuscript are appreciated.

1 COUPLAND. R.T. and T.C. BRAYSHAW 1953. The fescue grassland in Saskatchewan. Ecology 34:386-405.

2 JOHNSTON, A. and M.D. MacDONALD 1967. Floral initiation and seed production in Festuca scabrella Torr. Can. J. Plant Science 47:577-583.

3 MACOUN, J. 1882. Manitoba and the Great North-west. World Publ. Co., Guelph, Ont.

4 MOSS, E.H. 1932. The vegetation of Alberta. $1 \mathrm{~V}$. The poplar association and related vegetation of central Alberta. J. Ecol. 20: $380-415$.

5 MOSS, E.H. 1955. The vegetation of Alberta. Bot. Rev. 21:493-567.

6 PYLYPEC, B. 1986. The Kernen Prairie - A relict fescue grassland near Saskatoon, Saskatchewan. Blue Jay 44:222-231. 